\title{
Self-Determination in Indigenous Online Education
}

\author{
Colin Madland \\ Faculty of Education \\ University of Victoria \\ Jean-Paul Restoule \\ Professor and Chair \\ Indigenous Education \\ University of Victoria
}

\section{Correspondence: \\ Colin Madland \\ Faculty of Education \\ University of Victoria \\ Email: cmadland [at] uvic.ca}

\begin{abstract}
There is a pressing need, as outlined in the recommendations of the Truth and Reconciliation Commission of Canada, to promote success for Indigenous learners in higher education. One pathway towards greater participation and success may be to empower Indigenous learners to engage with open source digital tools and platforms that promote digital self-determination. This review of the literature will explore the concept of digital selfdetermination through examples of Indigenous communities claiming control over the infrastructure that serves their homes.
\end{abstract}

Keywords: digital self-determination, Indigenous learners, online 
We acknowledge and respect the lək'wəクən peoples on whose traditional territory the University of Victoria stands and the Songhees, Esquimalt and WSÁNEĆ peoples whose historical relationships with the land continue to this day.

In the Canadian context, one of the most pressing needs for justice is embodied in the lives and communities of the Indigenous Peoples who have stewarded this land since time immemorial. From the beginning of European colonization and continuing today, Indigenous Peoples have experienced broken promises, forced dispossession of land, relocation of communities, abduction of children, extremely high rates of self-harm and suicide, and unjust inaction in prosecuting crimes against Indigenous women and children, which finally led to the declaration that the Canadian government is guilty of genocide against Indigenous Peoples (A Legal Analysis of Genocide, 2019).

\section{Our Positions in Relation to the Paper}

\section{Colin}

Prior to outlining the challenge, and following Absolon and Willett (2005), I turn to a brief discussion of locating myself in relation to and my interest in the challenge and also to "land, language, spiritual, cosmological, political, economical, environmental, and social elements in [my] life" (p. 2). My name is Colin Michael Madland. I am an uninvited settler who lives on unceded syilx (Okanagan) territory (About Westbank First Nation Westbank First Nation, n.d.). I was born on Tk'emlúps te Secwépemc land and spent much of my childhood playing in and exploring the forest and rivers around my home. As a settler, it is very easy to ignore the history and context of my presence here, but as I embarked on this investigation, I began to explore that history and context, culminating in the publication of a critical family history (Freeman, 2000; Sleeter, 2016) on my personal website (Madland, 2019). My family name, Madland, provides a direct connection to my great grandfather, Ole Madland, who, heeding the call to settle in North America, emigrated from Norway, having had his path cleared by the political and physical dispossession of the Indigenous peoples deemed to be in the way.

Having a clear-eyed vision of my own history has dissolved any notion that I might be able to sidestep responsibility for working to end the ongoing dispossession of Indigenous peoples, or, as Absolon and Willett describe it, the "dis-membering" ( $p$. 4) of their families due to the Indian Act in Canada. Instead, I approach this work as an act supporting the "re-membering" (Absolon \& Willett, 2005, p. 4) of Indigenous people.

As a white settler, I am aware of the tremendous damage done by researchers seeking to impose colonial ideas on Indigenous communities and I trust that the words and ideas here accurately and fairly communicate the original intent of those who write from their lived experiences as Indigenous people. Where I fail in that goal, I invite dialogue so that I might listen and learn.

\section{Jean-Paul}

Boozhoo. Jean-Paul Restoule nintishinikaas. Wajask nitootem. Okikendawt mnissing nitoonciba. Anishinaabe ndaaw. This greeting and introduction in Anishinaabemowin, a.k.a. the Ojibwe language, tells a fellow Anishinaabe some key information. It 
communicates my name, my clan, my community, and my people. In about ten words I give a knowledgeable Anishinaabe much of what they need to know about who I am and where I come from. Anything else I say afterward can be contextualized by this standard introduction. This greeting communicates a series of relationships that grow ever wider, from the self, to the clan, to the community, to the nation. Extending beyond myself, I am related to all other humans and all living beings in Creation.

I am Jean-Paul Restoule. I belong to the muskrat clan. I'm a member of Dokis First Nation. I am a partner to the Robinson-Huron Treaty of 1850. I grew up in Orangeville, northwest of Toronto, and have lived in Anishinaabe territory all my life until 2017 when I moved to lək'wənən territory. I am a grateful visitor to the traditional territories of the Songhees and Esquimalt First Nations where I now chair the Department of Indigenous Education at the University of Victoria. Every day I learn something new about this land and I look forward to more and more learning about the language, culture, and beings of this place and what my responsibilities are in relation and reciprocity.

\section{Online Learning and Indigenous Education}

One of the primary tools of oppression was education through the abduction and forced relocation of Indigenous children to residential schools where mistreatment and abuse were commonplace. It is unsurprising then that public education continues to traumatize Indigenous communities. Indigenous people in B.C. attain fewer post-secondary credentials compared to non-Indigenous British Columbians. Based on the latest available data, $48 \%$ of Indigenous people in B.C. have attained a post-secondary certificate, diploma, or degree compared with $65 \%$ of non-Indigenous people in B.C., a difference of $17 \%$ (Statistics Canada, 2017). This disparity is accompanied by Indigenous people earning lower salaries, having fewer options for career advancement, and being less able to participate equitably in Canadian society. In 2015, the Truth and Reconciliation Commission of Canada published 94 calls to action, seven of which directly address education for Indigenous people including the elimination of educational and employment gaps within one generation; improving educational attainment; providing equitable funding; developing for-credit, culturally appropriate curricula; enabling parental and community responsibility, control, and accountability; and ending the backlog of Indigenous students seeking post-secondary education (The Truth and Reconciliation Commission of Canada, 2015).

Tessaro et al. (2018) argue that online learning may play a role in enhancing access to formal educational opportunities for Indigenous Peoples, yet also point out that there may be incompatibilities between the First Peoples Principles of Learning (First Nations Education Steering Committee, 2008) and typical online learning structures. It is possible, however, that some of their concerns result from a conflation of the pedagogy of online learning practices that were previously delimited to text for bandwidth obstacles that are increasingly no longer present with both the modality of online learning (when and where learning happens) and the technology of online learning (the supporting hardware, software and network infrastructure). 


\section{Invasive and Extractive Infrastructure}

Certainly, there are challenges with the technology infrastructure upon which online education is built and is deployed, because the technology, or platform, is not neutral. Kwet (2019) highlights the stark parallels between the dark colonial past (and present) of South Africa where Europeans created a system of economic domination by controlling the architecture of commercial enterprises and modern day 'investments' in technology by US-based tech monopolies. One way early colonizers accomplished this was by building railways that originated in the gold and diamond mines and travelled directly to ports on the coast, bypassing local towns who would have benefitted from being involved in the supply chain. Instead, all of the profits went directly back to Europe. This might be called 'extractive resource capitalism' and it has been a tool for colonization from the very beginning of colonialism.

Today, GAFAM (Google/Alphabet, Amazon, Facebook, Apple, and Microsoft) engages in digital colonialism, termed "surveillance capitalism" by Zuboff (2015), by controlling the three pillars of technological infrastructure: software, hardware, and network connectivity (Kwet, 2019). At the software level, companies control what users are able to do through licensing agreements, Digital Rights Management (DRM), proprietary algorithms and code that users cannot see, understand, change, or share, and by tightly controlling which software can run on which hardware. Hardware controls are enacted by physically designing hardware in such a way that software cannot be changed, and more recently by encouraging, even forcing, users to outsource computing power to proprietary servers. Finally, GAFAM has begun exerting colonial dominance through ownership of the network itself as they have begun building the undersea cable networks that connect continents to the internet.

\section{Opportunities for Digital Self-Determination}

Fortunately, there are other platforms which are more hospitable to both Indigenous and effective online education. Open source software, such as WordPress, Grav (content management), Big Blue Button (video conferencing), Mastodon and Mattermost (social networking) all have the characteristic that they can be customized by end users to suit their own needs for privacy, sharing, distributing, or archiving. They also enable rich audio-visual interactions and the ability for users to contextualize their online presence and thereby represent themselves accurately.

When Indigenous learners in remote communities are empowered to control the flow of their own data through the use of software, hardware, and network connections that are under their own control and sovereignty, then they can begin to assert digital selfdetermination in their learning by presenting themselves online as they want to be represented rather than trying to fit their self-representation into a template designed by a software engineer in California. Further, when the platform that they use for their learning is in alignment with the First Peoples' Principles of Learning, they are potentially more likely to be able to stay in their home communities and support networks. This is not only an act that recognizes their connectedness to their community, but it is also an act of sovereignty over the land upon which they live and the networks within which they connect. 


\section{Seeking Alignment Between Open Education and Indigenous Education}

Online educators might learn from the work of scholars in open education, which is typically understood as being a set of beliefs, values, practices, and resources that, when enacted, increase access to educational environments for the benefit of marginalized, underrepresented, or under-served students. Educators who have surveyed the literature on the history of open education have found that early conceptions of open education were primarily focused on creating student-centred learning environments in K-12 (Cuban, 2004; Hendricks, 2017; Morgan, 2016) and, more specifically, three pairs of complementary values: "autonomy and interdependence; freedom and responsibility; democracy and participation" (Paquette, 2005). Morgan (2016) notes that these aims toward autonomy and freedom persist in the open education discourse today. For example, Lambert suggests that socially just learning experiences should be "primarily by and for the benefit and empowerment of non-privileged learners who may be under-represented in education systems" (2018, p. 239).

The idea that online education could be 'by and for' non-privileged learners is similar to Linda Tuhiwai Smith's (1999) conception of Indigenous research being centred on Indigenous selfdetermination (see Figure 1).

\section{Figure 1}

\section{The Indigenous Research Agenda}

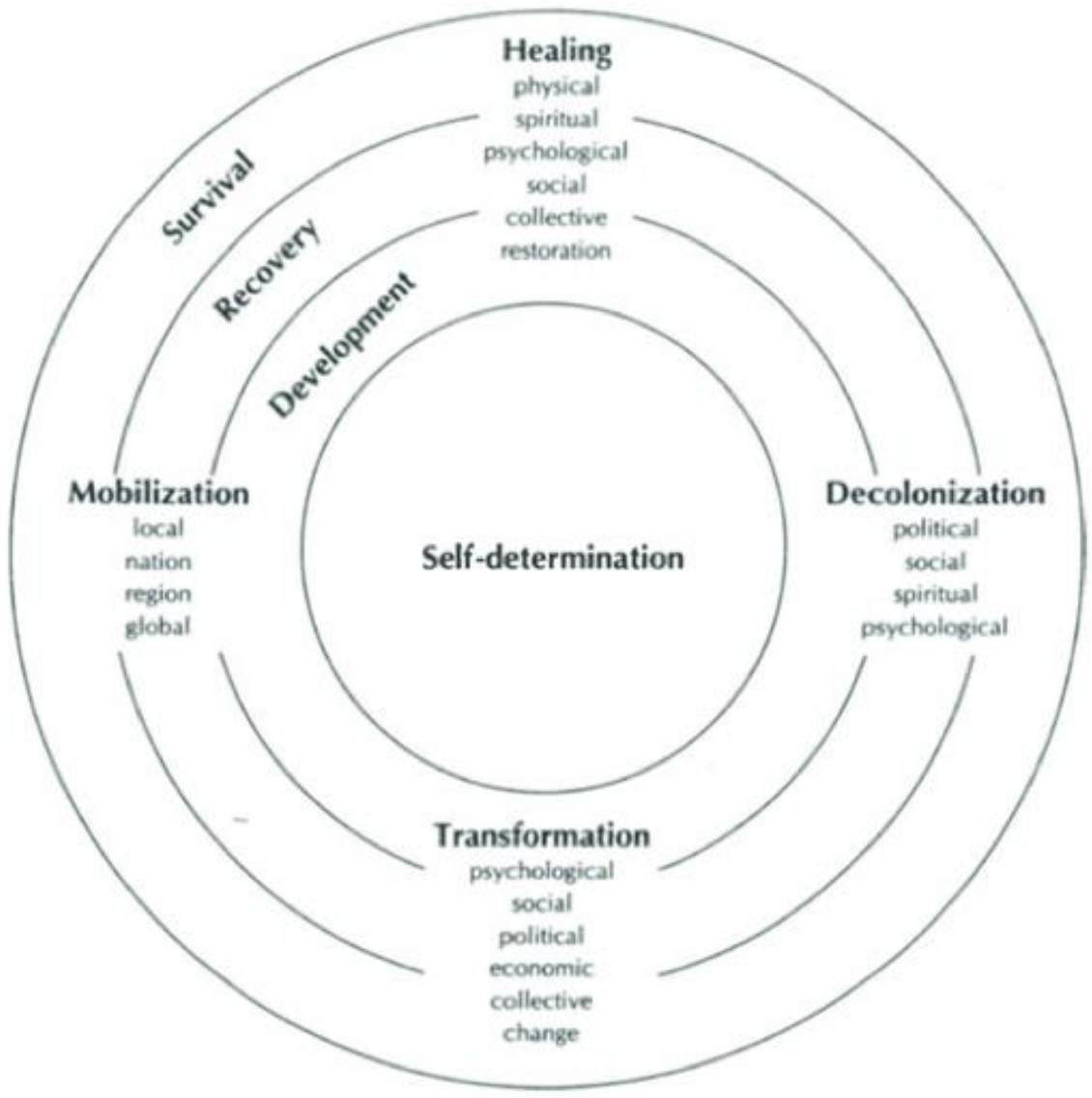

Note. Image is reproduced exactly from Decolonizing methodologies: Research and indigenous peoples by Linda Tuhiwai Smith, 1999, p. 117. 
Smith uses the metaphor of ocean tides, which represent "movement, change, process, life, inward and outward flows of ideas, reflections and actions" (P. 116), in alignment with her people's relationship with the Pacific Ocean. The tides, shown as concentric circles, are survival, recovery, development, and self-determination, and they represent "states of being through which Indigenous peoples are moving" (p. 116). These are not necessarily sequential states, because the recovery process must be prioritized based on local needs and the external forces over which Indigenous peoples currently have no control. The end goal for Indigenous people, however, is always self-determination.

Indigenous educators may be encouraged that challenges with both the technological infrastructure and didactic, text-based pedagogies may be overcome with a focus on learnercentred modalities as practiced by open educators to support the First Peoples Principles of Learning and the building of platforms and networks based on open source software and systems.

\section{Author's Contributions}

Colin Madland is the lead author and Jean-Paul Restoule provided critical insight as an Indigenous researcher.

\section{Open Researcher and Contributor Identifier (ORCID)}

Colin Madland (iD https://orcid.org/0000-0002-1761-1903

Jean-Paul Restoule (iD https://orcid.org/0000-0001-6225-3773

\section{Ethics Statement}

Ethics review was not required for this literature review.

\section{Conflict of Interest}

The author does not declare any conflict of interest.

\section{References}

About Westbank First Nation-Westbank First Nation. (n.d.). Retrieved January 14, 2022, from https://www.wfn.ca/our-community/about-westbank-first-nation.htm

Absolon, K., \& Willett, C. (2005). Putting Ourselves forward: Location in Aboriginal Research. In L. Brown \& S. Strega (Eds.), Research as Resistance: Critical, Indigenous, and AntiOppressive Approaches. Canadian Scholar's Press, Inc. [CSPI]; eBook Collection (EBSCOhost). http://ezproxy.library.uvic.ca/login?url=https://search.ebscohost.com/login.aspx?direct=tr $\underline{u e \& d b=n l e b k \& A N=145914 \& \text { site=ehost-live \&scope=site }}$

Cuban, L. (2004). The Open Classroom. Education Next, 4(2). Retrieved from https://www.educationnext.org/theopenclassroom/

First Nations Education Steering Committee. (2008). First Peoples Principles of Learning. First Nations Education Steering Committee. http://www.fnesc.ca/wp/wpcontent/uploads/2015/09/PUB-LFP-POSTER-Principles-of-Learning-First-Peoplesposter-11x17.pdf 
Freeman, V. (2000). Distant relations: How my ancestors colonized North America. M \& S.

Hendricks, C. (2017). Open Education in the 60s and 70s - You're the Teacher. Retrieved October 19, 2018, from http://blogs.ubc.ca/chendricks/2017/10/21/open-education-inthe-60s-and-70s/

Kwet, M. (2019). Digital colonialism: US empire and the new imperialism in the Global South. Race \& Class, 0306396818823172. https://doi.org/10.1177/0306396818823172

Lambert, S. R. (2018). Changing our (Dis)Course: A Distinctive Social Justice Aligned Definition of Open Education. Journal of Learning for Development - JL4D, 5(3). Retrieved from http://www.j|4d.org/index.php/ej|4d/article/view/290

Madland, C. (2019, December). Critical Family History [Blog]. Colin M. Madland. https://grav.madland.ca/writing/timeline

Morgan, T. (2016, December 21). Open pedagogy and a very brief history of the concept. Retrieved October 15, 2018, from explorations in the ed tech world website: https://homonym.ca/uncategorized/open-pedagogy-and-a-very-brief-history-of-theconcept/

Sleeter, C. E. (2016). Critical Family History: Situating Family within Contexts of Power Relationships. Journal of Multidisciplinary Research (1947-2900), 8(1), 11-24.

Smith, L. T. (1999). Decolonizing methodologies: Research and indigenous peoples. London; New York: Dunedin, N.Z. : New York: Zed Books ; University of Otago Press ; Distributed in the USA exclusively by St. Martin's Press.

Statistics Canada. (2017, November 29). Data tables, 2016 Census. Retrieved February 14, 2019, from Statistics Canada website: https://www12.statcan.gc.ca/censusrecensement/2016/dp-pd/dt-td/Rp-

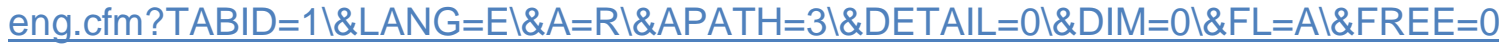
$1 \& \mathrm{GC}=59 \mid \& \mathrm{GL}=-$

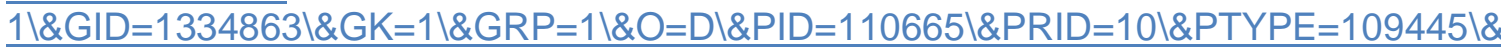
$\mathrm{S}=0 \backslash \& S H O W A L L=0 \backslash \& S U B=0 \backslash \& T e m p o r a|=2017 \backslash \& T H E M E=123 \backslash \& V I D=0 \backslash \& V N A M E E=| \& V$ $\mathrm{NAMEF}=\backslash \& \mathrm{D} 1=0 \backslash \& \mathrm{D} 2=0 \backslash \& \mathrm{D} 3=0 \backslash \& \mathrm{D} 4=2 \backslash \& \mathrm{D} 5=0 \backslash \& \mathrm{D} 6=0$

Tessaro, D., Restoule, J.-P., Gaviria, P., Flessa, J., Lindeman, C., \& Scully-Stewart, C. (2018). The Five R's for Indigenizing Online Learning: A Case Study of the First Nations Schools' Principals Course. Canadian Journal of Native Education, 40(1), 125-143.

The Truth and Reconciliation Commission of Canada. (2015). Truth and Reconciliation Commission of Canada: Calls to Action. Retrieved from https://ehprnh2mwo3.exactdn.com/wpcontent/uploads/2021/01/Calls to Action English2.pdf

Zuboff, S. (2015). Big other: surveillance capitalism and the prospects of an information civilization. Journal of Information Technology, 30(1), 75-89. https://doi.org/10.1057/iit.2015.5

A Legal Analysis of Genocide. (2019). National Inquiry into Missing and Murdered Indigenous Women and Girls. https://www. mmiwg-ffada.ca/ 